\title{
PENGARUH PELATIHAN TENAGA KERJA TERHADAP JUMLAH PRODUKSI KULIT PADA LINGKUNGAN INDUSTRI KECIL (LIK) KABUPATEN MAGETAN
}

\author{
Ika Nor Wahyuni \\ Mahasiswa Prodi Ekonomi IKIP PGRI MADIUN
}

\begin{abstract}
This study aims to determine the skin workforce training entrepreneurs in Environment Industri Kecil (LIK) Magetan, to determine the amount of production in the skin entrepreneurs Environment Industri Kecil (LIK) Magetan, and to find out how the influence of the number of workforce training leather production in the Environment Industri Kecil (LIK) Magetan. The samples in this study used a sample of employers in the region aimed at the Lingkungan Industri Kecil (LIK) who attended training in UPT Industri Kulit dan Produk Kulit Magetan who are 32 employers. Data collection using questionnaires and documentation. In analyzing the data in the study using the product moment correlation test, $\mathrm{F}$ test and $\mathrm{t}$ test. In analysis regression results in correlation values obtained for $\mathrm{r}_{\text {count }}$ $0.668 \geq \mathrm{r}_{\text {table }}$ of 0,349 or $\operatorname{Sig}_{\text {hit }} 0,000 \leq \operatorname{Sig}_{\text {prob }} 0.05$ means training workers had skin relation to total production in the Lingkungan Industri Kecil (LIK) Magetan. While the Fisher test values obtained $\mathrm{F}_{\text {count }} 24.135 \geq \mathrm{F}_{\text {table }} 4.17$ or $\operatorname{Sig}_{\text {hit }} 0,000 \leq \operatorname{Sig}_{\text {prob }} 0.05$ means workforce training have an influence on the amount of skin on the production of Environment Industri Kecil (LIK) Magetan.
\end{abstract}

Keyword: workforce training, the amount of production.

Abstrak: Penelitian ini bertujuan untuk menentukan pekerjaan kulit pengusaha pelatihan tenaga Lingkungan Industri Kecil (LIK) Magetan, untuk menentukan jumlah produksi di pengusaha kulit Lingkungan Industri Kecil (LIK) Magetan, dan untuk mengetahui bagaimana pengaruh jumlah kulit pelatihan tenaga kerja produksi di Lingkungan Industri Kecil (LIK) Magetan. Sampel dalam penelitian ini menggunakan sampel di Lingkungan Industri Kecil (LIK) yang mengikuti pelatihan di UPT Industri Kulit dan Produk Kulit Magetan yang berjumlah 32 pengusaha. Pengumpulan data menggunakan dokumentasi pertanyaan. Dalam menganalisis data dalam penelitian ini menggunakan uji korelasi product moment, uji F dan uji t. Dalam hasil regresi nilai korelasi data analisis diperoleh untuk menghitung $0.668 \geq \mathrm{r}_{\text {tabel }}$ dari 0349 atau $\operatorname{Sig}_{\text {hit }} 0000 \leq \operatorname{Sig}_{\text {prob }} 0.05$ berarti pekerja pelatihan tenaga kerja memiliki hubungan untuk total produksi di Lingkungan Industri Kecil (LIK) Magetan. Sedangkan nilai uji Fisher diperoleh $F_{\text {hitung }} 24,135 \geq F_{\text {tabel }} 4,17$ atau $\operatorname{Sig}_{\text {hit }} 0,000 \leq$ $\mathrm{Sig}_{\text {prob }} 0,05$ berarti pelatihan tenaga kerja memiliki pengaruh pada jumlah kulit pada produksi Lingkungan Industri Kecil (LIK) Magetan.

Kata kunci: pelatihan tenaga kerja, jumlah produksi.

\section{PENDAHULUAN}

Seiring dengan kemajuan pada sektor industri nasional maupun pada tingkat regional, perkembangan industri kecil di
Kabupaten Magetan cukup menggembirakan. Hal ini tercermin dalam peningkatan jumlah unit usaha, nilai investasi, tenaga kerja, nilai produksi, serta nilai tambah yang 
dihasilkan. Sehingga semakin berkembangnya jenis dan produk industri kecil di daerah ini.

Suatu industri akan mengalami perkembangan bila suatu industri tersebut mampu meningkatkan jumlah produksinya. Dalam melaksanakan kegiatan produksi dengan tujuan utama memuaskan pelanggan, maka kegiatan produksi dilaksanakan sedemikian rupa sehingga kebutuhan pelanggan dapat dipenuhi tepat waktu, tepat mutu, pada jumlah produksi yang tinggi. Kebanyakan organisasi bisnis yang berhasil mencapai tujuannya yaitu mereka yang selalu berusaha untuk memberikan produk atau jasa yang ditawarkan sesuai dengan keinginan pelanggan. Menurut Agus Ahyari (2002: 11) "besarnya jumlah produksi, sedikit banyak akan tergantung pada kapasitas yang tersedia (terpasang) dalam perusahaan yang bersangkutan".

Dalam kegiatan produksi tidak lepas dari peran tenaga kerja, karena sangat dominan untuk melancarkan kegiatan produksi hingga memperoleh hasil produksi dari suatu kegiatan produksi. Diharapkan tenaga kerja memiliki karakteristik ketrampilan bekerja dan wawasan pengetahuan yang luas, profesional, produktif, serta memiliki etos kerja yang tinggi. Sehingga mampu memberikan kontribusi yang berkualitas dan berkuantitas memadai terhadap pelayanan kebutuhan masyarakat dalam berbagai dimensi kehidupan.

Tenaga kerja sebagai sumber daya manusia menunjuk pada hakikat dan karakteristik kemanusiaan sesuai dengan nilai dan martabat kemanusiaannya, yakni dalam hubungan dengan Tuhan Yang Maha Esa, hubungan dengan ekosistem, dan hubungan dengan kebudayaan (Oemar Hamalik, 2001: 7). Di samping itu, tenaga kerja yang mempunyai ketrampilan di bidangnya diharapkan untuk ikut dalam pelatihan yang biasanya diadakan oleh pihak tertentu.

Pelatihan tenaga kerja merupakan hak setiap pekerja dalam rangka meningkatkan dan mengembangkan ketrampilan dan keahlian sesuai dengan bakat, minat, dan kemampuannya biasanya diselenggarakan oleh lembaga pelatihan pemerintah, swasta, dan perusahaan. Pelatihan mampu meningkatkan ketrampilan yang standar menjadi ahli bahkan mahir dalam bidangnya. Menurut Ambar Teguh Sulistiyani dan Rosidah (2003: 175) "pelatihan adalah proses sistimatik pengubahan perilaku para pegawai dalam suatu arah guna meningkatkan tujuan-tujuan organisasional". Sementara Oemar Hamalik, (2001:10) beranggapan "pelatihan merupakan suatu fungsi manajemen yang perlu dilaksanakan secara terus menerus dalam rangka pembinaan ketenagaan dalam suatu organisasi". Sedangkan Menurut Robert L. Mathis dan Jhon H. Jackson (209:301) "Pelatihan (training) adalah sebuah proses dimana orang mendapatkan kapabilitas untuk membantu pencapaian tujuan-tujuan organisasional".

Menurut Hani Handoko (2011: 103) ada dua tujuan program latihan dan pengembangan karyawan. "Pertama, latihan dan pengembangan dilakukan untuk menutup "gap" antara kecakapan atau kemampuan karyawan dengan permintaan jabatan. Kedua, program-program tersebut diharapkan dapat meningkatkan efisiensi dan efektivitas kerja karyawan dalam mencapai sasaran-sasaran kerja yang telah ditetapkan".

Sementara itu fungsi pelatihan menurut Oemar Hamalik (2001: 13) diantaranya: 1). Pelatihan berfungsi untuk memperbaiki perilaku (performance) kerja para peserta pelatihan itu.2). Pelatihan berfungsi untuk mempersiapkan promosi ketenagaan untuk jabatan yang lebih rumit dan sulit. 3). Pelatihan berfungsi untuk mempersiapkan tenaga kerja pada jabatan yang lebih tinggi yakni jabatan kepengawasan dan manajemen.

Sedangkan faktor-faktor yang perlu dipertimbangkan dalam pelatihan dan pengembangan menurut Anwar Prabu Mangkunegara (2005:45) diantaranya adalah: 1). Perbedaan individu pegawai. 2). 
Hubungan dengan jabatan analisis. 3). Motivasi. 4). Partisipasi aktif. 5). Seleksi peserta penataran. 6). Metode pelatihan dan pengembangan.

Adapun strategi pembinaan pelatihan tenaga kerja menurut Basir Barthos (2004: 98) bahwa, strategi pembinaan pelatihan diarahkan agar pelatihan kerja mampu memenuhi tuntutan pasar kerja. Dalam strategi pembinaan pelatihan dikenal adanya trilogi latihan kerja sebagai berikut: 1) Latihan kerja harus sesuai dengan kebutuhan pasar kerja dan kesempatan kerja. 2) Latihan kerja harus senantiasa mutakhir sesuai dengan perkembangan ilmu pengetahuan dan teknologi. 3) Latihan kerja merupakan kegiatan yang bersifat terpadu dalam arti proses kaitan dengan pendidikan, latihan dan pengembangan satu dengan yang lain.

Dengan demikian pelatihan tenaga kerja diselenggarakan dan diarahkan untuk membekali, meningkatkan, dan mengembangkan ketrampilan atau keahlian kerja guna meningkatkan kemampuan, produktifitas, dan kesejahteraan tenaga kerja.

Di lain pihak Departemen Pendidikan Nasional Ilmu Pengetahuan Sosial Ekonomi (2005:5) mengasumsikan bahwa pengertian produksi dalam arti sempit ialah suatu kegiatan untuk menghasilkan barang. Untuk pengertian produksi dalam arti luas ialah mencakup semua usaha/kegiatan manusia untuk menambah kegunaan suatu barang atau untuk menciptakan kegunaan/faedah baru atas barang dan jasa sehingga dapat memenuhi kebutuhan hidup manusia.

Adapun fungsi produksi menurut Henry Faizal Noor (2007: 149) bahwa fungsi produksi ditunjukkan dalam bentuk hubungan matematis antara faktor-faktor (input) produksi dengan keluaran (output) produksi. Penggunaan produksi akan membantu para pengambil keputusan produksi, untuk bagaimana mengolah faktor-faktor produksi secara optimal, sehingga akan menghasilkan produksi yang juga optimal. Maka fungsi produksi (Q) dapat dirumuskan sebagai berikut:
$\mathrm{Q}=$ fungsi (input) atau $\mathrm{Q}=$ fungsi (faktor produksi)

$\mathrm{Q}=\mathrm{f}$ (Bahan Baku, Penolong, Teknologi, Labour, Energi)

Fungsi produksi di atas dapat juga menunjukkan skala hasil yang didapat (return to scale), serta dapat menunjukkan hubungan salah satu input dengan hasil (return to factor).

Kegiatan produksi merupakan kegiatan untuk menciptakan kegunaan suatu barang. Menurut Departemen Pendidikan Nasional Ilmu Pengetahuan Sosial (2005: 12) bahwa jenis produksi berdasarkan hasil produksi dapat digolongkan menjadi dua jenis produksi sebagai berikut:

1) Produksi yang menghasilkan barang

Kegiatan produksi yang bertujuan untuk menghasilkan barang yang mempunyai nilai guna lebih dan siap untuk memenuhi kebutuhan. Misalnya: produksi roti, sepatu, baju, dan sebagainya.

2) Produksi yang menghasilkan jasa

Kegiatan produksi yang bertujuan untuk menghasilkan jasa yang mempunyai nilai guna lebih dan siap untuk memenuhi kebutuhan. Misalnya: jasa dokter, jasa angkutan, jasa warung telekomunikasi (Wartel) dan sebagainya.

Dimana Sri Joko (2004:99) berpendapat "jumlah produksi adalah tingkat produksi yang biasanya dinyatakan dalam jumlah unit barang yang diproduksi dan dijual". Sementara asumsi Agus Ahyari (2002: 11) "besarnya jumlah produksi, sedikit banyak akan tergantung kepada kapasitas yang tersedia (terpasang) pada perusahaan yang bersangkutan".

Suatu industri akan mengalami perkembangan bila suatu industri tersebut mampu meningkatkan jumlah produksinya. Dalam melaksanakan kegiatan produksi dengan tujuan utama memuaskan pelanggan, maka kegiatan produksi dilaksanakan sedemikian rupa sehingga kebutuhan pelanggan dapat dipenuhi tepat waktu, tepat 
mutu, pada jumlah produksi yang tinggi. Kebanyakan organisasi bisnis yang berhasil mencapai tujuannya yaitu mereka yang selalu berusaha untuk memberikan produk atau jasa yang ditawarkan sesuai dengan keinginan pelanggan.

Berdasarkan jumlah produksi yang harus memenuhi kuantitas dan kualitas pasar, maka akan memicu karyawan untuk menghasilkan produksi yang lebih banyak, berkualitas, dan mampu memenuhi permintaan konsumen. Kerjasama dan etos kerja yang tinggi antara pimpinan dan karyawan sangat diperlukan dalam upaya peningkatan jumlah produksi. Dalam suatu proses produksi, menjaga dan mempertahankan kualitas dan kuantitas produk harus dipertahankan, karena dapat memberikan citra yang mampu dikenali oleh masyarakat luas/konsumen.

Menurut Daryanto (2012: 96) bahwa pada hakikatnya, jumlah produksi akan banyak ditentukan oleh dua faktor yaitu:

1) Faktor teknis

Merupakan faktor yang berhubungan dengan pemakaian dan penerapan fasilitas produksi secara lebih baik, penerapan metode kerja yang lebih efektif dan efisien, dan atau penggunaan bahan baku yang lebih ekonomis.

2) Faktor manusia

Merupakan faktor yang mempunyai pengaruh terhadap usaha-usaha yang dilakukan manusia menyelesaikan pekerjaan. Faktor ini meliputi: pelatihan kerja, motivasi, disiplin, dan etos kerja.

Jumlah Produksi merupakan hasil dari kegiatan produksi yang berwujud barang. Di dalam hal ini perlu kiranya untuk diketahui bahwa terdapat perbadaan antara produk dan jasa, walaupun keduanya adalah merupakan hasil dari kegiatan produksi yang mempunyai wujud tertentu, sifat-sifat fisik dan kimia tertentu. Di samping itu akan terdapat tenggang waktu antara saat diproduksinya produk tersebut dengan saat dikonsumsikannya produk yang bersangkutan oleh konsumen produk tersebut.
Sudah barang tentu bahwa dengan adanya pelatihan tenaga kerja yang diadakan oleh pihak terkait yang diikuti oleh tenaga kerja yang berkompeten di bidangnya akan mempunyai pengaruh terhadap hasil akhir atau jumlah produksi yang dihasilkan dalam suatu perusahaan. Suatu kegiatan yang efektif dan efisien sangat menunjang jumlah produksi yang diharapkan oleh perusahaan untuk memenuhi permintaan pasar.

\section{KERANGKA BERFIKIR}

Kerangka berfikir merupakan model konseptual tentang bagaimana teori berhubungan dengan berbagai faktor yang telah diidentifikasi sebagai masalah yang penting. Kerangka berfikir juga membahas mengenai sintesa tentang hubungan antar variabel yang disusun dari berbagai teori yang telah dideskripsikan.

Dalam hal ini pelatihan tenaga kerja erat kaitannya dengan jumlah produksi. Pelatihan yang diadakan oleh pihak terkait berguna sebagai wadah untuk memberikan pengetahuan/informasi bagi mereka yang kurang pengetahuan. Selain itu pelatihan sebagai sarana/wadah untuk meningkatkan ketrampilan, etos kerja, dan moral kerja pengusaha atau tenaga kerja yang berguna untuk meningkatkan hasil produksinya atau jumlah produksi. Apabila pengusaha atau tenaga kerja sering mengikuti pelatihan, maka akan mempengaruhi jumlah produksi yang dihasilkan. Karena dengan diikutkannya pelatihan tenaga kerja maka akan diperoleh tambahan ketrampilan, sehingga hasil produksi meningkat baik kualitas maupun kuantitas.

Bertitik tolak atas uraian tersebut hubungan atau pengaruh antar variabel $\mathrm{X}$ (variabel independen) yaitu pelatihan tenaga kerja, sedangkan variabel Y (variabel dependen) yaitu jumlah produksi.

\section{METODE PENELITIAN}

Tempat penelitian dilaksanakan di UPT Industri Kulit dan Produk Kulit di LIK (Lingkungan Industri Kecil) Kabupaten 
Magetan dengan alamat Jl. Teuku Umar No. 5 Kecamatan Magetan Kabupaten Magetan.

Alasan dilaksanakan memilih tempat penelitian ini antara lain: (1) Belum pernah diadakan penelitian yang sejenis dengan penelitian yang dilakukan peneliti, sehingga diharapkan hasil penelitian lebih bermanfaat. (2) Lokasi industri tersebut mudah dijangkau karena tempatnya strategis. (3) Adanya kerjasama yang baik dari pihak industri. (4) Tersedianya data yang mendukung untuk penelitian ini.

Waktu yang diperlukan dalam penelitian ini yaitu selama 4 bulan dari bulan Februari 2013 sampai dengan bulan Mei 2013.

Rancangan penelitian yang digunakan dalam penelitian ini adalah penelitian kausalkomparatif. Penelitian ini bertujuan untuk menyelidiki kemungkinan sebab-akibat berdasarkan pengamatan terhadap akibat yang ada, mencari kembali fakta yang mungkin menjadi penyebab melalui data tersebut. Penelitian kausal komparatif bersifat "ex postfacta artinya dikumpulkan setelah semua kejadian yang diperoleh berlangsung atau lewat" (Cholid Narbuko dan Abu Achmadi, 2003: 49).

Metode yang digunakan dalam penelitian ini adalah penelitian kuantitatif. Menurut Iqbal Hasan (2006:30) "analisis kuantitatif adalah analisis yang menggunakan alat analisis bersifat kuantitatif, yaitu alat analisis yang menggunakan model-model, seperti model matematika (misalnya fungsi multifariat), model statistik, dan ekonometrik". Hasil analisis disajikan dalam bentuk angka-angka yang kemudian dijelaskan dan diinterprestasikan dalam suatu uraian.

\begin{tabular}{|c|c|}
$\begin{array}{c}\text { PELATIHAN } \\
\text { TENAGA } \\
\text { KERJA }\end{array}$ & $\begin{array}{c}\text { JUMLAH } \\
\text { PRODUKSI }\end{array}$ \\
\hline
\end{tabular}

Gambar Rancangan Penelitian
Dalam penelitian ini terdapat dua variabel yang digunakan yaitu:

\section{Variabel Independen (variabel bebas)}

"Variabel independen adalah variabel yang mempengaruhi atau yang menjadi sebab perubahannya atau timbulnya variabel dependen (terikat)" (Sugiyono, 2007:39). Dalam penelitian ini variabel bebas adalah pelatihan tenaga kerja (X). Indikator pelatihan tenaga kerja antara lain: (a) Ketrampilan kerja. (b) Semangat kerja. (c) Moral kerja.

\section{Variabel Dependen (variabel terikat)}

"Variabel dependen adalah variabel yang dipengaruhi atau yang menjadi akibat karena adanya variabel bebas" (Sugiyono, 2007:39). Dalam penelitian ini variabel terikat adalah jumlah produksi (Y). Indikator jumlah produksi adalah hasil produksi kulit.

\section{Populasi, Sampel, dan Teknik Peng- ambilan Sampel}

\section{Populasi}

Menurut Suharsimi Arikunto (2010: 173) "Populasi adalah keseluruhan objek penelitian". Sedangkan menurut Husaini Usman dan Purnomo Setiyadi Akbar (2004:43) "Populasi ialah semua nilai baik hasil perhitungan maupun pengukuran, baik kuantitatif maupun kualitatif, daripada karakteristik tertentu mengenai sekelompok objek yang lengkap dan jelas".

Adapun yang menjadi populasi dalam penelitian ini adalah pengusaha yang memproduksi kulit pada "Lingkungan Industri Kecil (LIK) Kabupaten Magetan” berjumlah 123 industri kecil.

\section{Sampel}

Suharsimi Arikunto (2010:174) berpendapat "Sampel adalah sebagian atau wakil populasi yang diteliti". Sedangkan menurut Husaini Usman dan Purnomo Setiyadi Akbar (2004:44) "Sampel (contoh) ialah sebagian anggota populasi yang diambil dengan menggunakan teknik tertentu yang disebut dengan teknik sampling".

Adapun yang menjadi sampel penelitian pada "Lingkungan Industri Kecil (LIK) 
Kabupaten Magetan” yaitu sebanyak 32 pengusaha kulit.

\section{Teknik Pengambilan Sampel}

Menurut Husaini Usman dan Purnomo Setiyadi Akbar (2004:44) teknik sampling berguna untuk:

a. Mereduksi anggota populasi menjadi anggota sampel yang mewakili populasinya (representatif), sehingga kesimpulan terhadap populasi dapat dipertanggungjawabkan.

b. Lebih teliti menghitung yang sedikit daripada yang banyak.

c. Menghemat waktu, tenaga, dan biaya.

Teknik pengambilan sampel dalam penelitian ini menggunakan Sampel Bertujuan atau Purposive Sampel. Menurut Suharsimi Arikunto (2010:183) "Sampel bertujuan dilakukan dengan cara mengambil subjek bukan didasarkan atas strata, random atau daerah tetapi didasarkan atas adanya tujuan tertentu".

\section{Teknik Pengumpulan Data}

Data-data yang diperlukan untuk penelitian dikumpulkan dengan teknik pengumpulan data. Dalam penelitian ini teknik pengumpulan data yang digunakan adalah:

\section{Angket atau Kuesioner}

"Kuesioner adalah sejumlah pertanyaan tertulis yang digunakan untuk memperoleh informasi dari responden dalam arti laporan tentang pribadinya, atau hal-hal yang ia ketahui”" (Suharsimi Arikunto, 2010:194). Sedangkan menurut Iqbal Hasan (2006:24) "Penggunaan kuesioner adalah cara pengumpulan data dengan menggunakan daftar pertanyaan (angket) atau daftar isian terhadap obyek yang diteliti (populasi atau sampel)".

Dari pengertian di atas dapat disimpulkan, kuesioner merupakan tenik pengumpulan data dengan memberikan daftar pertanyaan kepada responden. Teknik pengumpulan data berupa angket atau kuesioner ini digunakan untuk mengambil data tentang pelatihan tenaga kerja.
Dalam penelitian ini, kuesioner atau angket digunakan untuk mendapatkan laporan tentang pribadi responden mengenai tanggapan masing-masing dalam pelatihan yang diikutinya.

\section{Dokumentasi}

Menurut Suharsimi Arikunto (2010: 274) "Dokumentasi adalah mencari data mengenai hal-hal atau variabel yang berupa catatan, transkip, buku, surat kabar, majalah, prasasti, notulen rapat, lengger, agenda, dan sebagainya".

Dalam penelitian ini dokumentasi untuk mendapatkan data-data yang sudah ada mengenai sejarah, profil pengusaha kulit, dan data jumlah produksi yang diperlukan peneliti pada Lingkungan Industri Kecil (LIK) Kabupaten Magetan.

\section{Teknik Analisis Data}

Analisis data dalam penelitian ini menggunakan program SPSS (Statistical Product and Service Solution) for windows versi 16.0. Analisis data yang digunakan dalam penelitian ini adalah:

\section{Uji Instrumen}

Uji instrumen digunakan untuk menguji instrumen yang digunakan dalam penelitian ini yaitu angket. Uji instrumen yang dilakukan ada 2 yaitu:

a. Uji Validitas

Validitas adalah seberapa jauh alat dapat mengukur hal atau subjek yang akan diukur (Iqbal Hasan, 2006:15). Sedangkan Suharsimi Arikunto (2010:211-212) menyatakan "validitas adalah suatu ukuran yang menunjukkan tingkat-tingkat kevalidan atau kesahihan suatu instrumen". Dengan demikian validitas data merupakan ukuran untuk menunjukkan sejauh mana kevalidan dari suatu instrument. Instrumen dikatakan valid apabila instrument tersebut dapat mengungkapkan data variabel yang diteliti secara tepat.

Dalam uji validitas yang digunakan dengan metode product moment yaitu dengan mengkorelasikan antara skor tiap item dengan 
skor total. Rumus dan kriteria yang digunakan untuk uji validitas adalah sebagai berikut:

Rumus untuk menguji validitas kuesioner, digunakan rumus korelasi product moment daripearson:

$$
r_{x y}=\frac{\sum x y}{\sqrt{\left(\sum x^{2}\right)\left(\sum y^{2}\right)}}
$$

(Sugiyono, 2004:212)

Keterangan:

$\mathrm{r}=$ koefisien korelasi

$\mathrm{n}=$ jumlah observasi/responden

$\mathrm{X}=$ skor pertanyaan

$\mathrm{Y}=$ skor total

\section{b. Uji Reliabilitas}

"Reliabilitas adalah seberapa jauh konsistensi alat ukur untuk dapat memberikan hasil yang sama dalam mengukur hal dan subjek yang sama" (Iqbal Hasan, 2006:15).

Uji reliabilitas yang digunakan pada penelitian yaitu menggunakan metode cronbach alpha. Rumus dan kriteria yang digunakan untuk uji reliabilitas adalah sebagai berikut:

Rumus yang digunakan untuk menguji reliabilitas menggunakan metode Cronbach Alpha sebagai berikut:

$$
r_{11}=\left(\frac{k}{(k-1)}\right)\left(1-\frac{\sum \sigma_{b}^{2}}{\sigma_{t}^{2}}\right)
$$

Keterangan:

(Suharsimi Arikunto, 2010:239)

$r_{11} \quad=$ reliabilitas instrument

$K=$ banyak butir pertanyaan

$\sigma_{t}^{2}=$ varians total

$\Sigma_{\sigma_{b}}^{2}=$ jumlah varians butir

\section{Analisis Data}

Dalam penelitian ini analisis yang digunakan untuk mencari pengaruh pelatihan tenaga kerja terhadap jumlah produksi menggunakan regresi linier. Dengan uji regresi linier sederhana dapat diketahui uji hipotesis menggunakan alat bantu SPSS for windows 16.

Setelah data penelitian terkumpul, selanjutnya adalah menganalisis data tersebut melalui perhitungan statistik untuk menguji hipotesis untuk mencari koefisien pengaruh pelatihan tenaga kerja terhadap jumlah produksi.

Menurut Iqbal Hasan (2006:63) "Regresi linear sederhana adalah regresi linear dimana variabel yang terlibat di dalamnya hanya dua, yaitu satu variabel terikat Y, dan satu variabel bebas $\mathrm{X}$ serta berpangkat satu". Regresi sederhana atau bivariat merupakan suatu prosedur untuk mendapatkan hubungan matematika dalam bentuk suatu persamaan antara variabel criterion atau variabel tidak bebas tunggal dengan variabel predictor atau variabel bebas tunggal. Rumus regresi linear sederhana adalah sebagai berikut:

$$
\mathbf{Y}=\mathbf{a}+\mathbf{b X}
$$

(Iqbal Hasan, 2006:64)

Keterangan:

$\mathrm{Y}=$ variabel terikat (variabel yang diduga)

$\mathrm{X}=$ variabel bebas

$\mathrm{a}=$ intersep (nilai konstanta)

$\mathrm{b}=$ koefisien regresi (slop)

Untuk melihat bentuk korelasi antar variabel dengan persamaan regresi tersebut maka nilai a dan $\mathrm{b}$ harus ditentukan terlebih dahulu.

$\mathrm{b}=\frac{n \Sigma X Y-(\Sigma X)(\Sigma Y)}{\Sigma X^{2}-(\Sigma X)^{2}}$
$\mathrm{a}=\frac{\Sigma Y-b \Sigma X}{n}$

(Iqbal Hasan, 2006:64)

Dalam analisis regresi memuat uji korelasi, uji Fisher, dan uji t. Keterangan pada masing-masing uji tersebut adalah:

\section{Korelasi}

Analisis korelasi ini menggunakan korelasi product moment merupakan uji korelasi digunakan untuk mencari keeratan hubungan antara dua variabel. 
a. Rumus Korelasi

Rumus yang digunakan untuk uji korelasi adalah:

$$
r=\frac{n \sum X Y-\left(\sum X\right)\left(\sum Y\right)}{\left\{n \sum X^{2}-\left(\sum X\right)^{2}\right\}\left\{n \sum Y^{2}-\left(\sum Y\right)^{2}\right\}}
$$

(Iqbal Hasan, 2006: 62)

b. Kriteria Untuk Korelasi

Uji korelasi dalam penelitian ini digunakan kriteria dengan terlebih dahulu menentukan hipotesisnya. Hipotesis yang digunakan dalam penelitian ini adalah sebagai berikut:

1) $H_{0}$ ditolak apabila nilai $\operatorname{Sign}_{h i t} \leq \operatorname{Sign}_{\text {prob }}$ atau $r_{\text {hitung }} \geq r_{\text {tabel }}$ dapat diartikan ada hubungan pelatihan tenaga kerja terhadap jumlah produksi pada Lingkungan Industri Kecil (LIK) Kabupaten Magetan.

2) $H_{0}$ diterima apabila nilai $\operatorname{Sign}_{h i t} \geq$ Sign $n_{\text {prob }}$ atau $r_{\text {hitung }} \leq r_{\text {tabel }}$ dapat diartikan tidak ada hubungan pelatihan tenaga kerja terhadap jumlah produksi pada Lingkungan Industri Kecil (LIK) Kabupaten Magetan.

\section{Uji Fisher (F)}

Uji (F) merupakan suatu alat analisis yang digunakan untuk mengetahui apakah semua variabel bebas (X) secara bersamasama mempunyai pengaruh yang signifikan terhadap variabel terikat (Y). Rumus, kriteria, dan probabilitas untuk uji Fisher adalah sebagai berikut:

a. Rumus uji Fisher

$$
F_{h}=\frac{R^{2} / k}{\left(1-R^{2}\right) /(n-k-1)}
$$

(Sugiyono, 2004:223)

Dimana:

$\mathrm{R}=$ Koefisien korelasi ganda

$\mathrm{k}=$ Jumlah variabel independen

$\mathrm{n}=$ Jumlah anggota sampel b. Kriteria Pengujian

Kriteria ini digunakan dalam pengujian hipotesis. Untuk uji Fisher hipotesis yang digunakan adalah sebagai berikut:

1) $H_{0}$ ditolak apabila $F_{\text {hitung }} \geq F_{\text {tabel }}$ berarti ada pengaruh pelatihan tenaga kerja terhadap jumlah produksi pada Lingkungan Industri Kecil (LIK) Kabupaten Magetan.

2) $H_{0}$ diterima apabila $F_{\text {hitung }} \leq F_{\text {tabel }}$ berarti tidak ada pengaruh pelatihan tenaga kerja terhadap jumlah produksi pada Lingkungan Industri Kecil (LIK) Kabupaten Magetan.

3. Ujit

Uji $\mathrm{t}$ merupakan suatu alat analisis untuk mengetahui apakah variabel bebas (X) mempunyai pengaruh secara signifikan terhadap variabel terikat $(\mathrm{Y})$.

a. Rumus Ujit

$$
t=\frac{r \sqrt{n-2}}{\sqrt{1-r^{2}}}
$$

(Sugiyono, 2004: 214)

Keterangan:

$\mathrm{r}=$ koefisien korelasi sederhana

$\mathrm{n}=$ jumlah data atau kasus

\section{b. Kriteria Pengujian}

Kriteria ini digunakan dalam pengujian hipotesis untuk uji t. Hipotesis yang digunakan adalah sebagai berikut:

1) $H_{0}$ ditolak apabila $t_{\text {hitung }} \geq t_{\text {tabel }}$ berarti ada beda pengaruh pelatihan tenaga kerja terhadap jumlah produksi pada Lingkungan Industri Kecil (LIK) Kabupaten Magetan.

2) $H_{0}$ diterima apabila $t_{\text {hitung }} \leq t_{\text {tabel }}$ berarti tidak ada beda pengaruh pelatihan tenaga kerja terhadap jumlah produksi pada Lingkungan Industri Kecil (LIK) Kabupaten Magetan. 


\section{HASIL PENELITIAN}

\section{Variabel Pelatihan Tenaga Kerja}

Deskripsi dari variabel pelatihan tenaga kerja dengan jumlah data $(\mathrm{N})$ sebanyak 32 mempunyai deskripsi data sebagai berikut: (a) Nilai jumlah total skor sebesar 2070; (b) Nilai mean sebesar 64,69; (c) Nilai median sebesar 64,00; (d) Nilai modus sebesar 62; (e) Nilai standar deviasi sebesar 3,115; (f) Nilai minimum sebesar 60; (g) Nilai maximum sebesar 71 .

\section{Variabel Jumlah Produksi}

Deskripsi dari variabel jumlah produksi dengan jumlah data $(\mathrm{N})$ sebanyak 32 mempunyai deskripsi data sebagai berikut: (a) Nilai jumlah total skor sebesar 6542,4; (b) Nilai mean sebesar 204,450; (c) Nilai median sebesar 176,400; (d) Nilai modus sebesar 216,0; (e) Nilai standar deviasi sebesar 1.2147E2; (f) Nilai minimum sebesar 43,2; (g) Nilai maximum sebesar 608,0.

\section{Hasil Uji Korelasi}

Hasil uji korelasi didapat besarnya nilai $\mathrm{r}_{\text {hitung }}$ sebesar 0,668 sedangkan $\mathrm{r}_{\text {tabel }}$ sebesar 0,349. Di lain pihak nilai Sig $_{\text {hit }}$ sebesar 0,000 dan $\operatorname{Sig}_{\text {prob }}$ sebesar 0,05 . Hal ini berarti nilai $r_{\text {hitung }} \geq r_{\text {tabel }}(0,668 \geq 0,349)$ atau $\operatorname{Sig}_{\text {hit }} \leq \operatorname{Sig}_{\text {prob }}$ $(0,000 \leq 0,05)$. Atas dasar uji korelasi tersebut dapat disimpulkan bahwa $\mathrm{H}_{0}$ ditolak, artinya ada hubungan antara pelatihan tenaga kerja terhadap jumlah produksi kulit pada Lingkungan Industri Kecil (LIK) Kabupaten Magetan. Di lain pihak uji determinasi diperoleh nilai $\mathrm{R}^{2}$ ( $\mathrm{R}$ Square) atau koefisien determinasi yang dipergunakan untuk mengetahui seberapa besar prosentase sumbangan pelatihan tenaga kerja terhadap jumlah produksi mempunyai nilai $\mathrm{R}^{2}$ adalah 0,446 . Jadi sumbangan pelatihan tenaga kerja terhadap jumlah produksi yaitu 44,6\% sedangkan sisanya sebesar $55,40 \%$ dipengaruhi oleh faktor lain.

\section{Hasil Uji Fisher}

Dari hasil Uji Fisher diperoleh besarnya nilai $\mathrm{F}_{\text {hitung }}$ sebesar 24,135 sedangkan nilai $\mathrm{F}_{\text {tabel }}$ sebesar 4,17. Di lain pihak nilai $\mathrm{Sig}_{\text {hit }}$ sebesar 0,000 dan $\mathrm{Sig}_{\text {prob }}$ sebesar 0,05. Hal ini berarti bahwa nilai $\mathrm{F}_{\text {hitung }} \geq \mathrm{F}_{\text {tabel }}(24,135 \geq$ 4,17) dan $\operatorname{Sig}_{\text {hit }} \leq \operatorname{Sig}_{\text {prob }}(0,000 \leq 0,05)$. Atas dasar Uji Fisher tersebut dapat disimpulkan bahwa $\mathrm{H}_{0}$ ditolak, artinya ada pengaruh pelatihan tenaga kerja terhadap jumlah produksi kulit pada Lingkungan Industri Kecil(LIK) Magetan.

\section{Hasil Uji t}

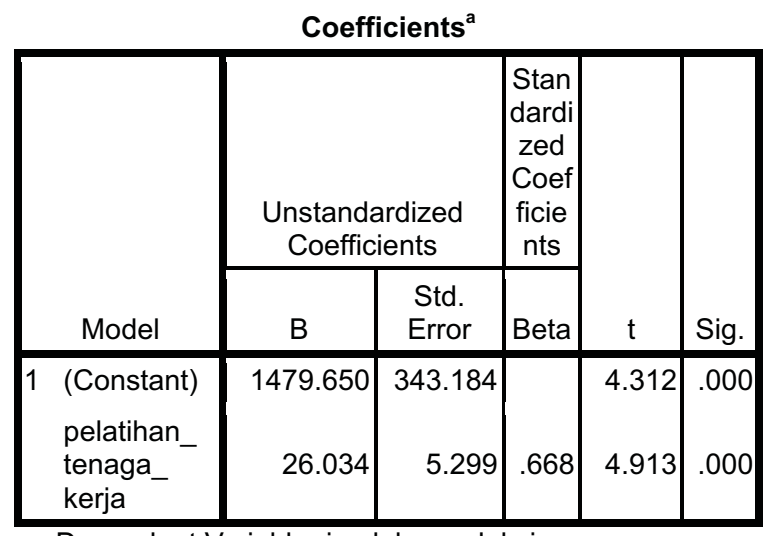

a. Dependent Variable: jumlah_produksi

Atas dasar tabel di atas uji $\mathrm{t}$ diperoleh nilai $t_{\text {hitung }}$ sebesar 4,913 $\geq \mathrm{t}_{\text {tabel }}$ sebesar 1,697 atau nilai $\operatorname{Sig}_{\text {hit }}$ sebesar $0,000 \leq \operatorname{Sig}_{\text {prob }} 0,05$. Hal ini berarti nilai $\mathrm{t}_{\text {hitung }} \geq \mathrm{t}_{\text {tabel }}(4,913 \geq 1,697)$ atau $\operatorname{Sig}_{\text {hit }} \leq \operatorname{Sig}_{\text {prob }}(0,000 \leq 0,05)$. Dari hasil uji $\mathrm{t}$ tersebut dapat dikatakan bahwa $\mathrm{H}_{0}$ ditolak artinya ada beda pengaruh pelatihan tenaga kerja terhadap jumlah produksi kulit pada Lingkungan Industri Kecil (LIK) Magetan.

Lebih lanjut apabila dilihat dalam persamaan regresi diperoleh persamaan nilai $\mathrm{Y}=1479,650+26,034 \mathrm{X}$. Dari persamaan garis regresi tersebut dapat dilihat jika pelatihan tenaga kerja meningkat sebanyak 1\% jumlah produksi akan meningkat pula sebesar $26,034 \%$, sedangkan faktor lainnya tetap. 


\section{Simpulan dan Pembahasan Hasil Analisis}

Atas dasar hasil pengujian hipotesis dapat diambil simpulan sebagai berikut.

\section{Simpulan Uji Korelasi}

Hasil uji korelasi didapat besarnya nilai $\mathrm{r}_{\text {hitung }}$ sebesar 0,668 sedangkan $\mathrm{r}_{\text {tabel }}$ sebesar 0,349. Di lain pihak nilai Sig $_{\text {hit }}$ sebesar 0,000 dan $\operatorname{Sig}_{\text {prob }}$ sebesar 0,05. Hal ini berarti nilai $\mathrm{r}_{\text {hitung }} \geq \mathrm{r}_{\text {tabel }}(0,668 \geq 0,349)$ atau $\operatorname{Sig}_{\text {hit }} \leq \operatorname{Sig}_{\text {prob }}$ $(0,000 \leq 0,05)$. Selain itu diperoleh nilai $\mathrm{R}^{2}$ adalah 0,446 . Jadi sumbangan pelatihan tenaga kerja terhadap jumlah produksi yaitu $44,6 \%$.

Sesuai hipotesis yang diajukan dapat diperoleh simpulan bahwa ada hubungan antar pelatihan tenaga kerja terhadap jumlah produksi kulit pada Lingkungan Industri Kecil(LIK) Kabupaten Magetan.

\section{Simpulan Uji Fisher}

Hasil dari pengujian Fisher dapat diperoleh nilai $\mathrm{F}_{\text {hitung }}$ sebesar 24,135 sedangkan nilai $F_{\text {tabel }}$ sebesar 4,17. Di lain pihak nilai Sig $_{\text {hit }}$ sebesar 0,000 dan Sig $_{\text {prob }}$ sebesar 0,05. Hal ini berarti bahwa nilai $F_{\text {hitung }} \geq F_{\text {tabel }}$ $(24,135 \geq 4,17)$ dan $\operatorname{Sig}_{\text {hit }} \leq \operatorname{Sig}_{\text {prob }}(0,000 \leq$ $0,05)$.

Sesuai hipotesis yang diajukan dapat diperoleh simpulan bahwa ada pengaruh pelatihan tenaga kerja terhadap jumlah produksi kulit pada Lingkungan Industri Kecil(LIK) Kabupaten Magetan.

\section{Simpulan Ujit}

Hasil dari uji t dapat diperoleh nilai $t_{\text {hitung }}$ sebesar 4,913 $\geq \mathrm{t}_{\text {tabel }}$ sebesar 1,697 atau nilai $\mathrm{Sig}_{\text {hit }}$ sebesar $0,000 \leq \operatorname{Sig}_{\text {prob }}$ 0,05. Hal ini berarti nilai $t_{\text {hitung }} \geq t_{\text {tabel }}(4,913 \geq 1,697)$ atau $\operatorname{Sig}_{\text {hit }} \leq \operatorname{Sig}_{\text {prob }}(0,000 \leq 0,05)$. Sesuai hipotesis yang diajukan dapat diperoleh simpulan bahwa ada beda pengaruh pelatihan tenaga kerja terhadap jumlah produksi kulit pada Lingkungan Industri Kecil (LIK) Kabupaten Magetan. Berarti $\mathrm{H}_{0}$ ditolak dan $\mathrm{H}_{1}$ diterima.
Sehingga diperoleh persamaan nilai $Y=$ $1479,650+26,034 \mathrm{X}$, simpulannya adalah apabila pelatihan tenaga kerja ditingkatkan 1\% maka akan terjadi kenaikan jumlah produksi sebanyak $26,034 \%$ apabila faktor yang lain tetap.

\section{Pembahasan Uji Korelasi}

Untuk uji korelasi diperoleh nilai $r_{\text {hitung }}$ $(0,668) \geq r_{\text {tabel }}(0,349)$ atau $\operatorname{Sig}_{\text {hit }}(0,000) \leq$ $\mathrm{Sig}_{\text {prob }}$ pada taraf signifikansi $(0,05)$. Selain itu, dalam penelitian ini diperoleh $\mathrm{R}^{2}$ sebesar 0.446. Sehingga menunjukkan bahwa sebanyak $44,60 \%$ pelatihan tenaga kerja dipengaruhi oleh jumlah produksi.

Dengan hal ini $\mathrm{H}_{0}$ ditolak, artinya ada hubungan antara pelatihan tenaga kerja terhadap jumlah produksi kulit pada Lingkungan Industri Kecil(LIK) Magetan.

\section{Pembahasan Uji Fisher}

Untuk uji Fisher diperoleh nilai $\mathrm{F}_{\text {hitung }}$ $(24,135) \geq F_{\text {tabel }}(4,17)$ atau $\operatorname{Sig}_{\text {hit }}(0,000) \leq$ $\operatorname{Sig}_{\text {prob }}(0,05)$. Dengan hal ini $\mathrm{H}_{0}$ ditolak, artinya ada pengaruh pelatihan tenaga kerja terhadap jumlah produksi kulit pada Lingkungan Industri Kecil(LIK) Magetan.

\section{Pembahasan Ujit}

Untuk uji $t$ diperoleh nilai $t_{\text {hitung }}$ sebesar $4,913 \geq \mathrm{t}_{\text {tabel }}$ sebesar 1,697 atau nilai $\mathrm{Sig}_{\text {hit }}$ sebesar $0,000 \leq \operatorname{Sig}_{\text {prob }} 0,05$. Hal ini berarti nilai $\mathrm{t}_{\text {hitung }} \geq \mathrm{t}_{\text {tabel }}(4,913 \geq 1,697)$ atau $\operatorname{Sig}_{\text {hit }} \leq$ $\operatorname{Sig}_{\text {prob }}(0,000 \leq 0,05)$. Dengan demikian $\mathrm{H}_{0}$ ditolak, artinya ada beda pengaruh pelatihan tenaga kerja terhadap jumlah produksi kulit pada Lingkungan Industri Kecil (LIK) Magetan. Dimana diperoleh persamaan nilai $\mathrm{Y}=1479,650+26,034 \mathrm{X}$, artinya adalah apabila pelatihan tenaga kerja ditingkatkan 1\% maka akan terjadi kenaikan jumlah produksi sebanyak 26,034\% apabila faktor yang lain tetap.

Pelatihan merupakan kekuatan pendorong kegiatan seseorang ke arah tujuan 
tertentu dan melibatkan berbagai kemampuan yang dimiliki untuk mencapainya. Dari pengujian hipotesis di atas dapat ditarik kesimpulan bahwa pelatihan tenaga kerja mempunyai pengaruh sebesar $44,60 \%$ terhadap jumlah produksi. Dan ternyata dalam penelitian ditemukan bahwa ada responden/ pengusaha yang mempunyai nilai terendah justru mempunyai jumlah produksi yang tinggi. Dengan demikian dapat diartikan bahwa pengaruh sebesar $55,40 \%$ berasal dari faktor-faktor tertentu.

\section{PENUTUP}

\section{Simpulan}

Berdasarkan analisis data dan pembahasan yang telah diuraikan sebelumnya dapat diambil simpulan sebagai berikut:

a. Pelatihan tenaga kerja memiliki nilai ratarata sebesar 64,69 dengan nilai maksimum 71 , nilai minimum 60 , standar deviasi 3,115 , median 64,00 , dan modus sebesar 62. Dari hasil deskripsi variabel pelatihan tenaga kerja diketahui bahwa responden cenderung setuju terhadap pelatihan tenaga kerja yang diadakan oleh UPT setiap tahunnya (rata-rata 64,69), artinya bahwa pada umumnya responden setuju jika pihak UPT sering mengadakan pelatihan tenaga kerja.

b. Jumlah produksi memiliki rata-rata sebesar 204,450, dengan nilai maksimum 608,0 , nilai minimum 43,2 , standar deviasi 1.2147 E2, median 176,400 dan modus sebesar 216,0. Dari hasil deskripsi variabel jumlah produksi diketahui bahwa responden cenderung mempunyai jumlah produksi (rata-rata 204,405), artinya bahwa pada umumnya responden setuju semakin sering mengikuti pelatihan tenaga kerja akan meningkatkan jumlah produksi perusahaan tersebut.

c. Ada pengaruh pelatihan tenaga kerja terhadap jumlah produksi, hal ini dibuktikan dalam hasil anlisis regresi pada uji korelasi, uji F, dan uji t. Dalam hasil analisis regresi pada uji korelasi diperoleh nilai $r_{\text {hitung }}$ sebesar $0,668 \geq \mathrm{r}_{\text {tabel }}$ sebesar 0,349 atau $\operatorname{Sig}_{\text {hit }} 0,000 \leq \operatorname{Sig}_{\text {prob }} 0,05$ artinya pelatihan tenaga kerja mempunyai hubungan terhadap jumlah produksi kulit pada Lingkungan Industri Kecil (LIK) Magetan. Sementara pada uji Fisher diperoleh nilai $F_{\text {hitung }}$ sebesar $24,135 \geq$ nilai $F_{\text {tabel }}$ sebesar 4,17 atau $\operatorname{Sig}_{\text {hit }} 0,000 \leq \operatorname{Sig}_{\text {prob }}$ 0,05 artinya pelatihan tenaga kerja mempunyai pengaruh terhadap jumlah produksi kulit pada Lingkungan Industri Kecil (LIK) Magetan. Dan pada uji t diperoleh nilai $t_{\text {hitung }}$ sebesar $4,913 \geq \mathrm{t}_{\text {tabel }}$ sebesar 1,697 atau nilai Sig $_{\text {hit }}$ sebesar 0,000 $\leq \operatorname{Sig}_{\text {prob }} 0,05$ artinya ada beda pengaruh pelatihan tenaga kerja terhadap jumlah produksi kulit pada Lingkungan Industri Kecil (LIK) Magetan. Dari analisis regresi diperoleh persamaan $\mathrm{Y}=1479,650+$ 26,034 X berarti apabila pelatihan tenaga kerja meningkat sebanyak $1 \%$ maka jumlah produksi akan meningkat pula sebesar 26,034 X\%, sedangkan faktor lainnya dianggap tetap. Dari hasil koefisien determinasi atau $\mathrm{R}^{2}$ diperoleh prosentase sebesar $44,60 \%$ yang dipengaruhi oleh pelatihan tenaga kerja, sedangkan prosentase sebesar 55,40\% berasal dari faktor-faktor tertentu.

\section{Saran}

a. Bagi UPT Industri Kulit dan Produk Kulit Magetan

UPT (Unit Pelayanan Teknis) Industri Kulit dan Produk Kulit di LIK (Lingkungan Industri Kecil) Kabupaten Magetan perlu memperhatikan kualitas dan kuantitas perusahaan-perusahaan yang dibawahinya. Karena terbukti pelatihan tenaga kerja berpengaruh terhadap jumlah produksi.

b. Bagi Pengusaha di LIK (Lingkungan Industri Kecil) Magetan

Hendaknya para pengusaha mampu beradaptasi atau menyesuaikan diri dengan lingkungan industrinya. Karena dengan 
kesadaran untuk mengikuti pelatihan akan menghasilkan jumlah produksi yang berkualitas dan berkuantitas tinggi. Walaupun pelatihan tenaga kerja mempunyai prosentase pengaruh sebesar $44,60 \%$, dengan keaktifan pengusaha dalam ikut serta dalam pelatihan tenaga kerja akan menambah pengetahuan baik secara teoritis maupun praktis.

\section{c. Bagi Lembaga IKIP PGRI MADIUN}

Bagi peneliti yang akan datang sebaiknya mengadakan pengembangan penelitian ini dengan menggunakan variabel bebas selain pelatihan tenaga kerja. Karena selain pelatihan tenaga kerja masih banyak faktor yang mempengaruhi jumlah produksi. Faktor lain yang mempengaruhi jumlah produksi ini adalah pendidikan, pengalaman, lingkungan, motivasi, disiplin, dan etos kerja.

\section{DAFTAR PUSTAKA}

Agus Ahyari. 2002. Manajemen Produksi Perencanaan Sistem Produksi. Yogyakarta: BPFE.

Ambar Teguh Sulistyani dan Rosidah. 2003. Manajemen Sumberdaya Manusia. Yogyakarta: Graha Ilmu.

Anwar Prabu Mangkunegara. 2005. Manajemen Sumber Daya Manusia Perusahaan. Bandung: Remaja Rosdakarya.

Basir Barthos. 2004. Manajemen Sumber Daya Manusia. Jakarta: PT. Bumi Aksara.

Cholid Narbuko dan Abu Achmadi. 2003. Metodologi Penelitian. Jakarta: PT. Bumi Aksara.

Daryanto. 2012. Sari Kuliah Manajemen Produksi. Bandung: Satu Nusa.

Departement Pendidikan. 2005. Ilmu Pengetahuan Sosial-Ekonomi. Jakarta.
Hani Handoko. 2011. Manajemen Personalia dan Sumber Daya Manusia. Yogyakarta: BPFE

Henry Faizal Noor. 2007. Ekonomi Manajerial. Jakarta: PT. Raja Grasindo Persada.

Husaini Usman dan Purnomo Setyadi Akbar. 2004. Metodologi Penelitian Sosial. Jakarta: PT. Bumi Aksara.

Iqbal Hasan. 2006. Analisis Data Penelitian dengan Statistik. Jakarta: PT. Bumi Aksara.

L. Malthis Robert dan Jackson Jhon H. 2009. Human Resource Management. Jakarta: Salemba Empat.

Musa Hubeis. 2009. Prospek Usaha Kecil Dalam Wadah Inkubator Bisnis. Ghalia Indonesia.

Oemar Hamalik. 2001. Pengembangan Sumber Daya Manusia Manajemen Pelatihan Ketenagakerjaan. Jakarta: PT. Bumi Aksara.

Siswanto Sastrohadiwiryo. 2005. Manajemen Tenaga Kerja Indonesia. Jakarta: PT. Bumi Aksara.

Sugiarto, Tedy Herlambang, Brastoro, Brastoro, Rachmat Sudjana, Said Kelana. 2002. Ekonomi Mikro Sebuah Kajian Komprehensif. Jakarta: PT. Gramedia Pustaka Utama.

Suharsimi Arikunto. 2010. Prosedur Penelitian. Jakarta: PT. Rineka Cipta.

Sri Joko. 2004. Manajemen Produksi dan Operasi. Malang: Universitas Negeri Malang.

Sugiyono. 2004. Metode Penelitian Administrasi. Jl. Gegerkalong Hilir: CV. Alfa Beta.

Sugiyono. 2007. Metode Penelitian Kuantitatif, Kualitatif dan $R \& D$. Bandung: CV. Alfabeta. 
Sukaria Sinulingga. 2009. Perencanaan \& Pengendalian Produksi. Yogyakarta: Graha Ilmu.

Surya Darma. 2005. Manajemen Kinerja Falsafah, Teori dan Penerapannya. Yogyakarta: Pustaka Pelajar.
Zulian Yamit. 2003. Manajemen Produksi dan Operasi. Yogyakarta: CY Adipura.

file://HendaraPurwanto//:proses-produksiPengertian-Definisi-Jenis-ReliabilitasProses-Produksi.htm, (13/07/2013 5:35) 